\title{
Articles
}

\section{Japanese Nationalism and East Asia}

\author{
KATSURAJIMA Nobuhiro*
}

\section{Popular Nationalism}

The process of dissolution of "early modern empire" in East Asia and the formation of popular nationalism is situated between the end of the eighteenth and the end of the nineteenth centuries. ${ }^{1}$ Needless to say, the direct cause of this transformation was the eastern advance of world capitalism (the world=economics), but first, I will briefly summarize popular nationalism. ${ }^{2}$ In general, popular nationalism is a limited sense of belonging to a community imagined by the ancients as seen in texts. This sense of belonging is imagined to have been true for all of the people in the nation since ancient times; it could be said to constitute a fabrication in the temporal phase of the modern era. Ethnicity and ethnic consciousness are nothing but products of this process. The root of that sense of belonging lies in imagined linguistic, consanguineous, and cultural (emotional) communities. Nevertheless, despite the fact that analysis of the documents bequeathed to us by the ancients elucidates the imagined sense of belonging of only a small number of ancients, the impact of such texts extends into the modern era, and their authors are imagined as "peoples (ethnic groups) who existed historically."

* Ritsumeikan University

1 See my "Kinsei teikoku no kaitai to 19 seiki zenhanki no shisō dōkō" (Dissolution of Kinsei teikoku and Philosophical Trends in the Early Part of the Nineteenth Century”『近世帝国』の解体と 19 世紀前半期の思想動向 in Nihon shisōshi kōza 3 (Lectures on Japanese Intellectual History 3) 日本思想史講座 3 (Perikansha ペりかん社, 2012).

2 For information on popular nationalism I referred to the 2007 NTT Shuppan Japanese translation by Shiraishi Saya 白石さや of Benedict Anderson's Imagined Communities: Reflections on the Origin and Spread of Nationalism (originally published in 1983); Kang Sang-jung 姜尚中, Nashonarizumu (Nationalism) ナショナリズム (Iwanami Shoten 岩波書店, 2001); and Ōsawa Masachi 大澤真幸, Nashonarizumu no yūrai (Origins of Nationalism) ナショナ リズムの由来 (Kōdansha 講談社, 2007). 
These are imagined as self-evident. Of course, the print revolution and spread of vernacular language, as well as the role of the military, should not be discounted, but as Benedict Anderson postulates, a definitive role in the formulation of people's nationalism in nineteenth-century Europe was played by "editors of vernacular dictionaries, grammarians, linguists, and scholars of literature" in the formulation of an academic system for scholarship on ethnicity. This was an important moment in the fabrication of popular nationalism (imagination) globally in the twentieth century. Accordingly, popular nationalism became axiomatic during a long process that spanned some hundred years between the end of the eighteenth and beginning of the twentieth centuries. Ultimately, popular nationalism can be construed as becoming embedded in popular consciousness as the result of the paradigm in which imperialism constituted wars of aggression; schools, modern scholarship; and languages, national languages.

\section{Formation of Popular Nationalism in Tokugawa Japan}

The first occurrence of popular nationalism in Tokugawa Japan could be considered the formation of modern National Learning as represented by Motoori Norinaga (1730-1801). ${ }^{3}$ Tracing nationalism back to its origins, the first set of issues in modern National Learning after the debate on Japanese $u t a$ 歌 poetry and morality (Kokka hachiron), was the question of what new significance was to be attributed to the uta and classical Chinese poetry, which existed as class culture and ceremonies that transcended national boundaries, and in which people of various social strata were beginning to participate. ${ }^{4}$ Kada no Arimaro 荷田在満 (1706-1751) understood the concept as poetry for sport (ganka 習歌 or tawamure 觑れ), while Tayasu Munetake 田安宗武 (17151771) attempted to explain the issue using Zhu Xi-style moral prescriptions. The early period of the debate between Arimaro and Munetake was merely a demonstration of how contemporaneous $u t a$ were redefined, which was a continuation of questioning of the origins of $u t a$ and Chinese poetry divested of class culture, as well as its place in the culture of their day. ${ }^{5}$ Their cognition of the vicissitudes of $u t a$ in relation to those of classical Chinese poetry and their interpretations had more commonalities than differences. That is, it can be said that they and uta existed in an early modern imperial community.

3 Katsurajima Nobuhiro 桂島宣弘, Jita ninshiki no shisōshi (Intellectual History of Cognition of the Self and Others) 自他認識の思想史 (Yūshisha 有志舎, 2008).

4 Usami Kisohachi 宇佐美喜三八, Kinsei karon no kenkyū (Study of Early Modern Theories of Japanese Poetry) 近世歌論の研究 (Izumi Shoten 和泉書院, 1987).

5 Toki Zenmaru 土岐善麿, Zōtei Kokka hachiron (Enlarged and Revised Edition of Kokka hachiron) 増訂国歌八論 (Kaizōsha 改造社, 1943). 
Motoori Norinaga, however, published a commentary to Kokka hachiron that circulated among the intelligentsia and at the same time brought forward a new debate centered on issues of "Yamato kotoba" (native Japanese words) and the community of emotion. Prior to this was Kamo no Mabuchi's 賀茂真 淵 (1697-1769) praise of uta (poetry) in kamiyo 神代 (the age of the gods) and especially of the nature $u t a$ 歌 selected from the Manyōsh $\bar{u}$, which he considered the essence of uta. Mabuchi claimed that the "spirit of the age of the gods" could be known through "uta," and by extension, the "way of the gods" could also be known through what is "attained in nature." Mabuchi's emphasis on a "return to an ancient" natural, gentle "age of the gods" was equivalent to "restoration." There is a tendency to interpret restoration as a pre-modern historical consciousness rooted in a historical view of decline, but here Japan in the age of the gods is linked to Mabuchi's present (Tokugawa Japan). The focus must be on a temporally and successively completed interior that gives rise to thought. The philosophy of restoration in National Learning (as distinct from the philosophy of restoration found in Confucianism) gives rise to an imagined "historical Japan" through the structure in which the current era is reflected via the age of the gods. In his Goikō 語意考 and Kokuikō 国意考 Mabuchi conceptualized this as “the country where the sun rises." He extolled the fifty sounds of Japanese, the language of the "age of the gods," and criticized the country of the Tang (China).

It is noticeable that Motoori Norinaga's imagined "imperial nation's (Japan's) language of the age of the gods" goes a step beyond Mabuchi's. In Kokuikō, Mabuchi also states that "one can know the spirit and language of the age of the gods through uta from the age of the gods, and through that means, can understand the gods themselves." He advocated a method for elucidating "the way of the world of the gods" through the "language of the age of the gods." Yet in Goikō, Mabuchi understood the "sounds" in the language of the age of the gods to be "the natural sounds of heaven and earth" and did not change his stance that depended upon "nature." Thus, the "language of the gods" in Mabuchi can be found in "nature." Here vestiges of pre-Mabuchi early modern imperial thought can be seen. Motoori contrasted Chinese poetry, which "only expresses an unsettling rationalism," with Japan's "imperial" uta through which the "emotions and language of the age

6 I have used suitable modern translations for historical materials and quoted sections. Same below.

7 I used the versions of the Niimanabi 邇飛麻那微, Goikō 語意考, and Kokuiko 国意考 in the 19-volume Kamo no Mabuchi zenshū (Collected Works of Kamo no Mabuchi) 賀茂真淵全集 (Zoku Gunsho Ruijū Kankōkai 続群書類従刊行会, 1980). 
of the gods" via the "elegant spirit and language of the age of the gods" constitute the "disposition of the country of the gods." 8

While relying on this "spirit and language of the age of the gods," Motoori put forward a "difference" in languages fabricated in ancient times, thereby interpreting "the largely different" "state of language" as the core of communality. That is, "the separation between the interior and exterior in all things is of the utmost importance." The difference arising from "Japan as the interior and China as the exterior" (in Karaosame no ureta migoto 駆戎慨言) is clearly fabricated in "the language of the age of the gods," signifying a homogeneity of "the empire of Japan" from the "state of the language" interpreted as having absolutely no compatibility. At the end of the eighteenth century, Motoori's statement naturally was not yet a discourse that had acquired self-evidence. The role of modern scholarship was of definitive importance for the assertions by Motoori and others to become cultural literacy among the populace; indeed, a time span of over a century was necessary. It was the "discovery" of the work of Motoori and the Kojiki 古事 記 and Manyōshī 万葉集 through modern Japan's popular nationalism that made the discourse become a truism. ${ }^{9}$

Such assertions of National Learning arose in the peripheral "early modern empire," Tokugawa Japan, where Confucianism and Neo-Confucianism took root the latest of all. It could be said that the consolidated systematic and social Confucianism and Neo-Confucianism in Qing China and Joseon Korea were never amenable to popular nationalism. But it is not our place to evaluate the phenomenon positively or negatively. Rather, what must be scrutinized is the unequal rise of popular nationalisms within the "early modern empires" of East Asia. Eventually, this inequality strikingly damaged and impaired East Asian cooperation and unity.

\section{Modern Japanese Scholarship and East Asia: China}

It is said that prior to Muraoka Tsunetsugu 村岡典嗣 (1884-1946), Motoori was not considered a particularly important intellectual in Tokugawa Japan. ${ }^{10}$

8 I used the versions of Iso no kami no sesame goto 石上私淑言 and Karaosame no ureta migoto 馭戎慨言 in the Motoori Norinaga zensh $\bar{u}$ 本居宣長全集, Vols. 2 and 8 (Chikuma Shobo 筑摩書房, 1965-1993).

9 Koyasu Nobukuni 子安宣邦, “Norinaga mondai” to wa nanika (What Is the Norinaga Problem?「宣長問題」とは何か (Chikuma Shobo 筑摩書房, 2000); Shinada Yoshikazu 品田悦一 Manyōshū no hatsumei (Discovery of the Manyōshū) 万葉集の発明 (Shinyōsha 新曜社, 2001).

10 Maeda Tsutomu 前田勉, “Kaisetsu: Nihon shisōshigaku no tanjō” (Birth of Japanese Intellectual History: Commentary) 解説 一 日本思想史学の生誕 in Muraoka Tsunetsugu 村岡典嗣, Shinhen Nihon shisōshi kenkyū (New Edition: 
Even if there is no focus on Motoori, however, it must be said that modern Japanese scholarship, from its origin as successor to Motoori, and above all, national Japanese history, which is an inseparable part of nationalism, theorized Asia-especially China-expressly as the "other" for self-representation. That is, where national history was recorded and its qualities narrated, "things not of Japan," or "the source of Japan," as well as "things without common qualities" or "things with common qualities" assumed East Asia, and in particular, China, as the main actor in the background. Of course, the long shadow of Western Orientalism influenced the notion that East Asia (China) is "the other." In this sense, it is thought that it was the opposing position toward "contempt" by the West toward East Asia and China that invited such a structure. Inoue Tetsujirō井上哲次郎 (1856-1944), who is considered one of the individuals who established national Japanese history and Japanese intellectual history, stated: "When Japanese walk down Western streets...they are despised as Chinese. Being called a Chinese can be considered a slur." $\mathrm{He}$ plainly states that "in order to clarify the level of progress achieved by Japan," which differs from that of China, "it is imperative that we Japanese research historiography and disclose to Europe Japan's history so that they might know about it in Europe." Herein clearly lies "the value of Oriental history."11 Inoue eventually wrote the trilogy known as Nihon Yömeigakuha no tetsugaku 日本陽明学派之哲学 (Philosophy of Japan’s Wangyang Ming School; 1900), Nihon kogakuha no tetsugaku 日本古学派之哲学 (Philosophy of Japan's School of Ancient Learning, 1902), and Nihon Shushigakuha no tetsugaku 日本朱子学派之哲学 (Philosophy of Japan's Neo-Confucian School, 1905), which I will discuss below. Of course, these works were composed in order to "clarify the level of progress achieved by Japan."

There is, however, an even more essential background for the necessity of Japanese intellectual history to make China "an inescapable other" from the beginning in order to attain a self-representation that was coincidental with (and deeply related to) such counter Orientalism. Most works considered to be examples of National Learning (including works understood as manifesting "pure" Japanese philosophy such as the Kojiki and Manyōshū) were written in classical Chinese script (regardless of whether they were written in classical Chinese 漢文 or in Manyō-kana 万葉仮名) or were written directly in the language of Confucianism or Buddhism (that place over there: China) Even in this sense, it must be said that for the writing of Japanese intellectual

Research on Japanese Intellectual History) 新編日本思想史研究 (Heibonsha Tōyō Bunko 平凡社東洋文庫, 2004).

11 Shigakkai zasshi 史学会雑誌,Vol.24, 1891. In Inoue Tetsujirō shū 井上鉄次郎集, Vol.9 (Kuresu Shuppan クレス出版, 2003). 
history, Chinese script, and China, which came to be recognized as the birthplace of Chinese characters in the modern era, was from the beginning literally an "inescapable" entity for self-representation. ${ }^{12}$ What Motoori did earlier was to extirpate Chinese characters (kana-ji, 仮字) as the language of an "alien land." He stated that through the removal of kana-ji he wanted to secure the truism of "the imperial country," which foreshadows the experience of Japanese intellectual history in the modern period a priori.

Conversely, the fact that China could never be the "other" for Confucian intellectuals in Tokugawa Japan within the paradigm of "early modern empire" should not be overlooked. Looking solely at works on intellectual history, the Confucian history texts most representative of the Tokugawa era, Shinbun genry $\bar{u}$ 斯文源流, written by Kakuguchi Seisei 河口静斎 (1703-1754) in 1750, and Naba Rodō's 那波魯堂 (1727-1789) Gakumon genryū 学問源流 (1794), for example, reflect pithily on the conduct of Confucianists after Fujiwara Seika 藤原惺窝 (1561-1619) from the following perspective seen in Shinbun genryzu: "How can I possibly say that Confucianism, the canon of heaven and earth, is my own discourse? Adhering to personal theories and disdaining the saints and previous scholars is something small-minded people do." 13

Gakumon genryu $\bar{u}$ similarly describes the history of Confucianism, focusing on the period after Fujiwara Seika. In particular, Naba Rodō devotes many pages to the schools of Confucianism of Itō Jinsai 伊藤仁斎 (1627-1705), Ogyū Sorai 荻生徂徚 (1666-1728), and Yamazaki Ansai 山崎闇斎 (16191682). He criticizes their extreme theories and advocates instead a proper Neo-Confucianist stance. ${ }^{14}$ What is of most importance here is that none of

12 For information on China as "the inescapable other" I have relied heavily on Koyasu Nobukuni 子安宣邦, Kanji-ron 漢字論 (Iwanami Shoten 岩波書店, 2003). Koyasu subsequently has continued poignantly dissecting modern Japan (especially "Showa Japan") and the "China problem." I learned much from him for my discussion points here from his texts, "Ajia" wa do katararete kita ka $\Gamma \mathrm{P}$ ジア」はどう語られてきたか (Fujiwara Shoten 藤原書店, 2003) and Nihonjin wa Chügoku o dō kattate kita ka 日本人は中国をどう語ってきたか (Seidosha 青土 社, 2012), etc. In contrast, Korea has continued to be suppressed owing to its self-image. "China, which is always mentioned, and Korea, which is obscured," could be said to be important issues for examining the structure of Japan's self-image even today (as well as its own referenced scholarship), but here I must leave the "Korean problem" aside. Koyasu Nobukuni has also made keen observations on the "Korean problem" and narratives of national origins in Edo no shisō 江戸の思想,Vol.4, 1996.

13 In Kinko bungei onchi sōsho 近古文芸温知叢書, Vol.3 (Hakubunkan 博文館, 1891).

14 In Nihon bunko 日本文庫, Vol. 6 (Hakubunkan 博文館, 1891). 
the texts on intellectual history or the history of Confucianism in the Tokugawa era attempted to narrate histories of Japan or Japanese thought. There is mention of the differences between "them and us," as in: "The Koreans have Korean customs and Ryūkyū and Japan have Ryūkyūan and Japanese customs; such phraseology is unavoidable. The poetry by Qing Chinese has Qing Chinese expressions." Naba's main point was not to calibrate the singularity of each, but while recognizing divergence in era and place, to advocate "that of course the keystone of the truth of Confucianism could not be achieved without compositions and poetry, or without a truthful and honest heart." The "compositions and poetry" that Naba refers to were naturally written in classical Chinese. While acknowledging the "Japanese harmony in poetry recitations" 和気和習 (waki wash $\bar{u}$ ), the Gakumon genry $\bar{u}$ concludes that by striving for sincerity 誠 (makoto) it should be possible to arrive at the values common to China and Japan by excluding that "Japanese harmony in poetry recitations." In other words, China and Japan were perceived to share a unified world and era ("empire").

Accordingly, the otherization of China, premised on the dissolution of the "early modern empire" and severance of the imperial bond, was an inevitable structure based on the creation (fabrication) of Japan's self-image harking back to the beginning of the ancient era. These primordial structures were acknowledged by Motoori, as mentioned above, but can be considered problems encountered immediately at the point that Fukuzawa Yukichi 福沢諭吉 (1835-1901) wrote Bunmei-ron no gairyaku 文明論之概略 (1875) and Taguchi Ukichi 田口卯吉 (1855-1905) wrote Nihon kaika shōshi 日本開化小史 (18771882). It is common knowledge that Bunmei-ron no gairyaku presented China as the opposite extreme when it asserted that "Western civilization was the goal," but Nihon kaika shōshi also vividly narrates the same structure of tracing the civilization of Japan as a process whereby "what should be conveyed about ancient writing in our country today is that it actually began with classical Chinese," and from there, that "we write using Japanese grammar."

\section{Japanese Intellectual History and China}

Next I will examine how Japan and China were described at the end of the Meiji period, considered the beginning of Japanese intellectual history. First I will discuss the text Nihon Sōgakushi 日本宋学史 (1909) by Nishimura Tenshū (1865-1924). Of course, Nishimura became prominent as the chief editor of the Osaka Asahi shinbun 大阪朝日新聞. Here the issue under review is that he was already a scholar of Chinese classics who was aware of modern scholarship (and not a Confucianist). Nishimura states in the preface of the Nihon Sogakushi: 
The foundation of the ethics of our Japanese citizens derives from our intrinsic virtues since the age of the gods, influence of Confucianism that arrived in Japan during the reign of Emperor Ōjin, and promulgation of Buddhism that began in the reign of Emperor Kinmei (509-571). These three factors were forged in one "bellows."... Confucianism and Buddhism worked together and contributed greatly to improvement in ethics and development of the liberal arts. It must be said that it is this that makes our national polity different from that of China. With our unbroken line of emperors, and unique virtues from the age of the gods - which is as eternal as heaven and earth - as our essence, we have achieved a comprehensive assimilation of both Confucianism and Buddhism. Thus, Confucianism has become Japanese Confucianism, and Buddhism has become Japanese Buddhism. All three have become fused into one, and have cultivated the Japanese spirit and the way of the warrior (bushidō)..$^{15}$

Here the account in the Nihon Sogakushi from the end of the Meiji period describes thoroughly the kinds of perspectives and possibilities there were. Nishimura traces the establishment of "unique virtues," and interaction with the two "foreign philosophies" of Confucianism and Buddhism as a history of "harmony" and "comprehensive assimilation," the result of which was that "Japanese Confucianism," "Japanese Buddhism," the Japanese spirit," "the way of the warrior," and ultimately, "popular ethics" arose. That is, in Japanese intellectual history, the "unique value" of Japanese philosophy could be found by stripping away all "foreign thought." The notion of "comprehensive assimilation" of the "foreign philosophies" of Confucian and Buddhist thought to those "unique values" was itself Japanese philosophy. On the other hand, he had a strong awareness of the source of such philosophy, China, in which, unlike the "harmony" of Japanese Confucianism and Buddhism, "the essence of Confucianism was the expulsion of heresy," and "Buddhism labeled Confucianism and Daoism as heterodoxies, so that these mutual accusations have been made for a very long time."

I would like to elaborate a little more on how such theories formed the described framework (proprieties) of Japanese intellectual history at the time.

15 Published in 1909 by Ryōkōdo Shoten 梁江堂書店, pp. 1-8. For information on Nishimura Tenshū 西村天囚, see: Godaiin Yoshimasa 後醍院良正 (Original and Supplement) “Wakakihi no Tenshū”「(正・続) 若き日の天囚」in Kaitoku 懐徳, Vols. 36 and 37, 1968-1969; Umetani Noboru 梅溪昇, Osaka gakumonshi no shūhen 大阪学問史の周辺 (Shibunkaku Shuppan 思文閣出版, 1991); Machida Saburō 町田三郎, Meiji no Kangakusha tachi 明治の漢学者たち (Kenbun Shuppan 研文出版, 1998), etc. 
Haga Yaiichi's 芳賀矢一 (1867-1927) Kokuminsei jūron 国民性十論 (1907) became the forerunner of Nihonjinron (theories of Japanese identity) against the backdrop of Japan's leap into imperial status after the Russo-Japanese War (1904-1905). In Kokuminsei jūron, Haga states:

Our country was influenced from early times by Chinese culture, and took in Indian civilization through China. Furthermore, while the countries of the Orient today all atrophy, only our nation has entered the league of world powers. Recently, the effects of importing Western civilization have become strikingly notable. In what way was our country's culture influenced by the civilizations of India and China? To what extent did the people of our country absorb them and develop themselves? At the same time that we reflect on our happiness today, we must take serious precautions about our future. We must know the past to plan well for the future. ${ }^{16}$

Haga states plainly that "only our nation has entered the league of world powers" after the Russo-Japanese War, which is "our happiness today," and that to understand that process, the task should be assigned of learning how Japan was influenced by "Indian and Chinese civilizations," and how Japan "absorbed and developed them." When we examine Haga's ten "national traits" today, they certainly appear to be listed arbitrarily, but it must be noted that his references reflect a constant cognizance of the West and comparison with China. Examples include his statement that "Chinese also observe ancestor worship, but in revolutionary countries such as China, it is meaningless to link this attribute to the nation." Here "ancestor worship" is considered a Japanese "national trait."

The trilogy by Inoue Tetsujirō 井上哲次郎 mentioned earlier is perhaps the first comprehensive treatment of Tokugawa intellectual history. Comprised of Nihon Yömeigakuha no tetsugaku, Nihon kogakuha no tetsugaku, and Nihon Shushigakuha no tetsugaku, the trilogy contains the following such statements:

As expounded by Nakae Tojū 中江藤樹 (1608-1648), the ancient sages had a "Japanese spirit imbued with Chinese learning;" they analyzed the Chinese classics with a Japanese spirit, and without being consumed by the Chinese classics, our countrymen took the standpoints they should take, and resolutely established [Japanese philosophy]....Tojū emphasized filial piety the most among the various virtues. We should take

16 Fuzanbō hyakka bunko 8 Nihonjinron 冨山房百科文庫 8)日本人論 (Fuzanbō 冨 山房, 1977), p. 128. 
note of this point. Filial piety was the code of ethics of ancestor worship (Ahnenkultus). Wherever filial piety is found, ancestor worship is always present....Filial piety links ancestors and descendants; the fate of blood ties depends on the strength of the state of filial piety. The Japanese race, however, descends from one distant ancient tradition, and has never been thrown into confusion by other races since the founding of our country; we have formed one great blood-line and built a one-family nation because we have a homogenous language, manners, customs, and history....It is for this reason that the cult of filial piety has an important relationship with the destiny of the Japanese race. In particular, filial piety in Japan is the loyalty that is inside oneself. Because the nation of Japan is formed from one family system, just as one is filial to the father of the family, he is filial to the sovereign of the country. ${ }^{17}$

Nakae Tojū offers an evaluation from the viewpoint that they "analyzed the Chinese classics with a Japanese spirit, and without being consumed by the Chinese classics," and in particular portrays them as the embodiment of a "filial piety" that is the "code of ethics of ancestor worship" with an "important relationship with the destiny of the Japanese race." In addition, in Nihon kogakuha no tetsugaku the "activism" "unique to the Japanese race" is understood as being advocated through the Confucianists of the Kogaku School 古 学派 (School of Ancient Learning). For example, Yamaga Sokō's 山鹿素行 (1662-1685) "theory of the nation" is praised; his "theory of the morality of the samurai” also examines critically Nitobe Inazo's 新渡戸稲造 (1862-1933) Bushidō: The Soul of Japan, and evaluates the "constitution" of bushido, the "spirit of which continues in the minds of the masses." He regards Itō Jinsai's "activism" "not as negativism," but as the "manifestation of the nature of the Japanese race" "that innately requires active development." Further, in Nihon Shushigakuha no tetsugaku, Neo-Confucianism is ranked as "our own system of education during the three-hundred years of the Tokugawa, which has influenced greatly the development of national ethics." Through these volumes, the process of the unique development of Neo-Confucianism in Japan and the process of its convergence into a national ethical theory is portrayed. The eras are divided into three periods; the first two are described as a preparatory period for Neo-Confucianism to take root in Japan from its flowering under Fujiwara Seika to the Kansei Edict 宽政異 学禁 of 1790, which banned all forms of Confucianism except Neo-

17 Fuzanbō 冨山房, 1900, pp. 155-156. Subsequent quotes are from first editions of Nihon kogakuha no tetsugaku 日本古学派之哲学 and Nihon Shushiha no tetsugaku 日本朱子学派之哲学, which were all published by Fuzanbō Press. 
Confucianism. The third period is described thusly: "Even when direction was lost during the encounter with the tempestuous period of the Meiji Restoration, there was an eternal, indestructible truth in the ethical theory." Here, too, references are accompanied with declarations such as: "Confucianism is something that was produced together and was intoned by the Chinese intelligentsia as ethical education beginning with Confucius." "The people who came afterwards should have developed it even further, but they did not develop it very much. Among the Confucianists in Japan, Yamaga Sokō, Itō Jinsai, and Ogyū Sorai were such people, but none of the later people did anything."

As is clear above, whatever the content, the uniqueness of Japanese philosophy is assumed. Theories dealing with the development of Japanese philosophy, such as the manner of acceptance of the "two religions of Confucianism and Buddhism" stipulated as culture from abroad, "can be seen in Japan's own cultural homogeneity." It is possible to see how theories that understood the development of Japanese thought through interaction (inclusion, assimilation) with such foreign cultures arose as expressly modern academic knowledge. A surgical operation was performed on all Japanese thought until the end of the Tokugawa period using the two scalpels of uniqueness and difference. As an operation to extract Japan subjectively from East Asia and China, the process prescribed the "proprieties" of Japanese intellectual history.

Of course, if all self-expression is the product of the expression of the other, it is perhaps natural that the desire for self-expression inevitably accompanies such a structure or "proprieties." Nevertheless, the fact that the East Asia (early modern empire), and China that were formerly within are still understood with an extremely ambivalent feeling indicates that they must at the very least be functioning to shake the very foundations of the Japanese self-image. In that sense, Japanese popular nationalism and East Asia/China share a profound and inescapable relationship even today. In order to disentangle that relationship and create transnational scholarship, a means to face popular nationalism itself deconstructively must be sought. 